\title{
Democratization of Science and Biotechnological Development: Public Debate on GM Maize in South Africa
}

\author{
Pascal Newbourne Mwale*
}

\begin{abstract}
The Mandela government that came into power in 1994 made the democratization of science and technology a priority in post-apartheid South Africa. Attendant ideas of Science Communication and Public Understanding of Biotechnology have hitherto become currency in South Africa's public sector drive towards the democratization of science. Democratization of science and technology implies that the people, as non-experts, are an integral part of all deliberations on policy, regulation and control of science and technology, for example, in debates or controversies on issues arising from biotechnology. Democratization of science and technology is about the sociopolitical control of science and technology by the wider society. Science and technology must be controlled by the society at large because evil-minded groups of people can ill-use it to inflict harm on other groups of people. Moreover, certain unscrupulous and corrupt business entities can collude with the state and/or powerful and influential sociopolitical figures in societies to exploit and abuse indigenous scientific resources as well as endogenous modes of specialized scientific knowledge. On the latter, for example, they can evoke intellectual property rights (IPR) to patent resources that are not theirs historically. Thus, the ideal-type of democracy makes it imperative for the people of South Africa and of other societies in Africa to understand and actively participate in the development of science and technology. This necessitates increasing scholarly attention to be given to ques-
\end{abstract}

* Pascal Newbourne Mwale is Lecturer of Philosophy, Chancellor College, University of Malawi, Malawi, and currently Doctoral Research Fellow, The Constitution of Public Intellectual Life Research Project, University of the Witwatersrand, Johannesburg, South Africa.

E-mail: pmwale2003@yahoo.co.uk, Pascal-Mwale@wits.ac.za, 
tions of science communication and public understanding of science, arising at the intersection between science, society and politics in South and southern Africa. This paper discusses the role and importance of social movements in science communication and public understanding of biotechnology in South and southern Africa.

\section{Résumé}

Le régime de Mandela qui est arrivé au pouvoir en 1994 avait fait de la démocratisation de la science et de la technologie une priorité en Afrique du Sud postapartheid. Les idées qui vont avec les Sciences de la Communication et la Compréhension de la Biotechnologie par les Populations sont ainsi devenues monnaie courante dans les efforts faits au niveau du secteur public sud-africain en vue de la démocratisation de la science. La démocratisation de la science et de la technologie implique que la population, les profanes inclus, fassent partie intégrante de toutes les délibérations sur les politiques, la réglementation et le contrôle de la science et de la technologie, notamment les débats ou discussions sur des questions relatives à la biotechnologie. La démocratisation de la science et de la technologie renvoie au contrôle sociopolitique de la science et de la technologie par la grande frange de la population, étant donné que des groupes sociaux malintentionnés pourraient en faire un mauvais usage pour causer du tort à d'autres groupes d'individus. Par ailleurs, certaines entreprises sans scrupule et corrompues, de surcroît, pourraient s'associer à l'Etat et/ou à des personnalités sociopolitiques puissantes et influentes de la communauté pour exploiter et abuser des ressources scientifiques locales ainsi que des modes endogènes de la connaissance scientifique spécialisée. Pour ce qui concerne la connaissance scientifique spécialisée, par exemple, ces entreprises pourraient évoquer les droits de propriété intellectuelle (DPI) pour breveter des ressources qui ne leur appartenaient qui, historiquement, n'étaient pas les leurs. Par conséquent, le modèle idéal de la démocratie impose que les populations de l'Afrique du Sud et celles des autres sociétés africaines comprennent et participent activement à l'évolution de la science et de la technologie. Pour ce faire, il serait nécessaire qu'une plus grande attention cognitive soit accordée aux questions de la communication et de la compréhension de la science par les populations, notamment en ce qui concerne l'interconnexion entre la science, la société et la politique en Afrique australe, plus particulièrement en Afrique du Sud. Ce document aborde le rôle et l'importance des mouvements sociaux dans le domaine de la communication scientifique et dans la compréhension, par les populations, de la biotechnologie en Afrique du Sud et en Afrique australe

\section{Introduction}

This paper selects as a case the South African debate on GM maize. First, it looks at the background to the processes of the democratization of science in South Africa. Second, it puts the idea of 'civil society' in the crucible, that 
is, South Africa, examining specifically the nature, role, scope and limits of 'social movements' in science communication in South Africa. Biowatch SA's intervention into GM regulation in South Africa is selected as a specific instance of the case study. The overall aim of the paper is to help improve our understanding about the dynamics of public debate on biotechnology in South Africa by looking at the case of public debate on GM maize. Rather than attempt to arrive at neat and tight conclusions about the democratization of science as well as the attendant ideas of science communication and public understanding of science, the paper will further complicate these ideas with the hope of suggesting critical insights into the interaction between science, society and politics. The paper argues that inasmuch as the intervention of social movements might be the drivers of the democratization of science - as they help fill a gap filled neither by scientists nor news media practitioners - the conceptual morass in which the idea of civil society is swamped renders it extremely difficult for thinkers to readily appreciate its political potency and agency in Africa vis-à-vis biotechnological development. Civil society, as an idea, is ill-defined. ${ }^{1}$ The regrettable result is science miscommunication and public misunderstanding of biotechnology in South and southern Africa. To remedy science miscommunication and public misunderstanding of biotechnology, the paper recommends more issuespecific and multi-stakeholder studies around biotechnology at both country and regional level.

\section{The democratization of science, science communication and public understanding of biotechnology in South and southern Africa}

Southern African societies - just like their counterparts in the developed world in the post-Human Genome Project era - are yet to discover science fully. This is in spite of all the life-changing decisions and activities at the level of macro policy and decision-making within science communities and the state. After the dismantling of both dictatorial and racist regimes in southern Africa - totalitarian regimes that excluded the vast majority of the people from both politics and science - a crucial and urgent need arose in the emerging democratic regimes of the region for the democratization of science. The ideal-type of democracy makes it imperative for people of South Africa and whole societies in the region to understand and actively participate in developments in science and technology. ${ }^{2}$ The process of the consolidation of democracy has ignored, and failed dismally to recognize, the central place and crucial role of 'the people', that is, non-experts, in science and technology communication in the region. There is need for 'the democratization of science' in the region, and in Africa at large. 
There is a general consensus among theorists of democracy that the further development of the postcolonial African state will not be achieved without our being cognizant of and respecting the centrality of involving 'the people' in both policy- and decision-making as well as in actual developmental tasks. Catch-all phrases like 'participatory parity' (Fraser 1993), 'the bottomup approach' (Obadare 2004) and 'public understanding of science/ biotechnology', among others, attest to this realization on the part of theorists of democracy of the centrality of 'the people' in development. These phrases point to the need for broad-based, or community-wide, participation in developmental planning and implementation.

Perhaps because of the over-determination of the ideal-type of democracy, on the one hand, and the rapid pace of advances in science and technology, for example, biotechnology, on the other, the democratic imperative of participatory parity, or the all-inclusiveness of voices, in biotechnological policy-and decision-making has been low and poor, ${ }^{3}$ if not non-existent. ${ }^{4}$

At the continental level, biotechnology raises both hopes and fears in individuals and diverse groups of people in Africa because it has enormous implications for Africa's development. As Fukuyama (2002) argues, in biotechnology both the good and the bad are 'closely interconnected', and hence the need for tight political controls over biotechnological development, use or research (Fukuyama 2002: 181-2). Africa's involvement in the global biotechnology movement could lead to a shift in Africa's location, from the periphery to the centre of the global technology movement. Unlike other kinds of science and technology, biotechnology allows Africa to leapfrog; the operating knowledge is not contained only within the Euro-American cluster. African scientists, for example, are investigating various aspects of 80,000 cells that will collectively define genetic 'characteristics and proclivities' of every person on the globe. This repositioning of Africa in the global biotechnology movement and on the world market has enormous implications for the development of the continent, potentially leading to significant changes in global power politics and important shifts in international economic and trade relations. Biotechnology could positively change the position of Africa on the world market. ${ }^{5}$

\section{South Africa's public sector drive towards the democratization of science}

South Africa provides a relevant and an interesting context for beginning to study the problematic idea of the democratization of science as well as the attendant ideas of science communication and public understanding of science. In southern Africa, South Africa plays a leading role in biotechnology. South 
Africa, as the regional leader of biotechnological innovations, also becomes the crucible for testing new models of international agricultural economics as well as the initial market for multinational companies' ventures into biotechnology in southern Africa.

South Africa was the first southern African country to conduct experiments on GM cropping in 1997. GM crops, such as GM cotton, have been grown commercially in South Africa since 1997. The South African government gave its approval for commercial activities on GM maize cropping in 1998. A year later, in 1999, parliament passed the GMO Act. ${ }^{6}$ The South African National Biosafety Strategy was published in 2001. Futhi, a muchimproved South African dairy cow, was the first higher mammal to be cloned on the African continent in 2003. ${ }^{7}$ South Africa is currently engaged in innovative research on human migration patterns based on tracking of mitochondrial deoxyribonucleic acid (DNA). ${ }^{8}$

Impressive as these policy and practical strides the country has taken into the new biotechnology might look, the issues raised by biotechnology are knotty and sticky, and have led to profound and persistent disagreements in South Africa's public domains since the commercialization of GM crops in 1998. Since then, South Africa has found herself at the centre of intense and deep controversies surrounding GM cropping, stem cell research, cloning, antiretrovirals (arvs), among others, providing a regional platform for public debates on conflictual scientific issues that originated outside Africa. South Africa is, inescapably, the epicentre of public debate on GM technology. For Van der Walt, because of its leading position in science and technology in southern Africa, South Africa 'has become the primary biotechnological battleground in Africa' (Van der Walt 2000: 35).

As far as science and technology are concerned, post-apartheid South Africa has a big public sector drive. Science and technology are integral to human development in the new South Africa - no matter how development is characterized. According to the South African government's White Paper on Science and Technology (4 September 1996), South Africa will use science and technology to provide basic services, infrastructure and effective health for all South Africans and to become economically competitive on a global scale.

Since 1994, the state has made a number of landmark decisions and crucial initiatives to put the people at the centre of deliberations on policy, regulation and control of science and technology. For example, four years into the new dispensation, South Africa declared 1998 the Year of Science and Technology in South Africa (YEAST 1998). The aim of YEAST 1998 was to make South Africans more aware of how science and technology 
affected them in their everyday life. At present, South Africa is the only government in southern Africa that has a Science Communication unit and a Public Understanding of Biotechnology programme. The South African Agency for Science and Technology Advancement (SAASTA) houses both the unit and the programme. SAASTA is a business unit of the National Research Foundation (NRF). The Science Communication unit of SAASTA aims to develop and implement new science communication initiatives in response to national challenges and needs 'in line with international trends in the field of science communication'. ${ }^{9}$ As a concept, science communication is multistakeholder, bringing within its purview such players as scientists, news media practitioners, statespersons and politicians, and social movements-in short, it involves both expert and non-expert publics. The Public Understanding of Biotechnology programme of SAASTA aims to "promote a clear understanding of the potential of biotechnology and to ensure broad public awareness, dialogue and debate on its current and potential future applications, including Genetic Modification (GM)'. ${ }^{10}$ The Public Understanding of Biotechnology programme is committed to incorporating the views of nonexpert publics into discussions and debates on developments in biotechnology, especially in genetic modifications technology and its most notable products like GM maize. Additionally, South Africa initiated the Southern African Science Communication Network (SASCON), which is also housed by SAASTA. As a regional networking unit, SASCON 'believes that the way southern Africans understand, communicate and use science and technology significantly affects their economic, social and environmental wellbeing'. ${ }^{11}$ Thus, it aims to provide a forum for scientific knowledge and information exchange, to improve nonexpert publics' understandings of science, and to improve news media's engagement with science.

Thus, Mandela's vision to democratize science and technology explains South Africa's commitment to promoting science communication and public understanding of biotechnology. Overall, South Africa's drive towards the democratization of science and technology has (universalizable) justification. Non-experts are key social actors in science communication for at least three reasons. First, non-experts are the major consumers of products of science and technology. They ought to have a say in major decisions and activities of scientists and relevant government agencies. Secondly, scientists need the goodwill of non-experts in order to get public support and secure funding from the public sector for their research. Thirdly, recent surveys have shown that social perceptions of non-experts and those of the media are in approximate alignment with science news stories. In other words, non-experts play an important role in determining what science news stories 
make it to print or air (see, for example, Trumbo et al. 1998: 240; McInerney et al. 2004: 347; Tanner 2004: 353, 360).

One significant dimension of the problematic of the democratization of science is how non-experts can be said to understand, discuss and debate the latest developments in science and technology such as biotechnology and its most notable products. The question of the democratization of science is challenging because it is fundamentally about the participation of nonexperts in science and technology. ${ }^{12}$

Therefore, whereas the overall goal of the paper is to help improve our understanding about the dynamics of public debate on biotechnology in South Africa by looking at the case of public debate on GM maize, the paper actually isolates for illustrative and elucidatory purposes the particular case of Biowatch SA, a local social movement registered as an environmental non-governmental organization and it was formed in 1997.

\section{Social movements and the democratization of science}

Quite evidently then, the question that is still lingering is how to get nonexpert publics or 'the people' to discuss and debate biotechnology in particular or science and technology in general. In spite of a big public sector drive, there is a gap filled by neither the scientists nor the media in science communication and public understanding of biotechnology in South Africa. This is in spite of the fact that both scientists and news media practitioners claim to have social legitimacy because they uphold 'the public value' and work for 'the public interest'. Social movements try to fill the gap left by scientists and the news media. They evoke public value and public interest to try to legitimate their intervention in society. Social movements are important in public scientific controversy and public debate on biotechnology because - in spite of their well-known or traditional role as activists and lobbyists in the sociopolitical as well as ethical and cultural realms of society - they play a significant educational role as scientific information providers. Using appropriate mediating and dissemination instruments, especially the print news media, social movements articulate the basic science underlying the key scientific issues arising in the debate, thereby providing crucial detail about the basic science. They also fuel, or accentuate, public critique - which puts the evidence, legitimacy and credibility of the experiments and findings to question - by proffering the counter-science or the alternative scientific or quasi-scientific evidence. Thus, social movements can help us begin to appreciate not only the fate of science in public domains but also the extent to which science is vulnerable when it is exposed to public critical examination, 
outside its professional field of production, for example, the laboratory or the scientific community.

Non-experts stand to benefit significantly from social movements' role as educators, information providers and articulators of science in public debate on science. In South and southern Africa, and in the case of the experimental science of genetic modifications technology and its most notable products, social movements - if seen as activists and lobbyists - contribute greatly to the intensification of the controversy over experimental science in that they bolster and augment their arguments or reasoned opinions with non-scientific discourses such as human rights, democratic governance, colonialism and imperialism, postcolonial or post-independence development, and globalization discourses, among other non-scientific discourses. It can be suggested that by exploring social movements' public engagement in debate on controversial biotechnological products such as GM maize, it is possible to begin to notice clearly the problematic intersection between science, politics and society. An exploration of how one social movement intervened in GM regulation in South Africa is one of the most feasible ways of beginning to look closely at the problematic idea of the democratization of science.

\section{Biowatch SA takes the state and the biotech corporate industry to court}

South Africa did not itself experience food shortages in the 2001/2 season. The regional debate that was triggered by widespread acute hunger in the southern region forms the background to the court case in which Biowatch SA took the state and multinational GM seed company Monsanto and its allies and licensees to court on the behalf of 'the people' in what it called a 'public interest' case. Briefly, UN WFP offered GM maize, procured from the US, to hunger-stricken countries. The US-produced GM maize met with resistance in the region, which led to Zambia's total rejection of the GM maize grain and conditional acceptance by the majority of countries in the region. Biowatch SA sued both the state and the biotech industry in the Pretoria High Court in what turned out to be a rather protracted, emotive court trial, from 2004 to 2005. Biowatch SA accused them of withholding information from 'the people' on the risks and dangers of GM technology. It wanted the 'veil of secrecy' on information on GMOs to be removed. In its submissions to the high court, Biowatch SA argued that since July 2000, the Department of Agriculture had consistently denied it access to information on GM field trial licences or permits. In spite of that, Biowatch SA argued, South African law on GMOs - the GMO Act (1999) -specified that no modified crops could be released unless there had been a 'suitable and 
sufficient assessment of the risks' to human health and the environment. 'The people', who Biowatch SA claimed it represented, were entitled - or had a right of - access to information that affected their environment, and so the high court should have assessed for itself whether or not the information was 'genuinely confidential'.

The state (Department of Agriculture, the Executive Council for GMOs, and the Registrar for Genetic Resources) and the biotech industry (Monsanto and Stoneville Pedigree Seed Co.) counter-argued that some of the information Biowatch SA was seeking was 'confidential' and could not be disclosed to it. ${ }^{13}$ On 3 March 2005, the high court ruled in favour of Biowatch SA. In the ruling, the high court judge ordered the state to give Biowatch SA the information it had been requesting - but to which it had been denied access - for four years. ${ }^{14}$ On the next day, 4 March 2005, the Department of Agriculture reportedly began to prepare the information for Biowatch SA, in compliance with the high court order. ${ }^{15}$

Notably, soon after the high court drama the state instituted a study on the implications of GM maize imports on South Africa's export trade. The state put on hold GM maize imports into South Africa, implying that in the course of the studies no GM maize imports were allowed into South Africa. The study began in March 2005 and was scheduled to be completed early 2006. The Department of Trade and Industry launched a study to assess the implications of GM maize imports on South Africa's export trade. This staterun study was in response to society-wide concerns - as expressed by certain 'social movements' in various public forums -that GM maize imports would depress local maize prices and hinder robust exports to markets abroad where consumers rejected GM products. The department also launched two supplementary studies; the first, to assess the implications of GM products within the SADC region, where most countries had rejected GM products, and the second, to assess the trade implications for South Africa as an exporter of GM products. ${ }^{16}$

\section{Social movements and civil society in general}

Biowatch SA is a non-governmental organization (NGO) involved largely in environmental activism in South Africa. It is a 'social movement' (Greenstein, 2005). The high court case described above raises important questions, chief of which is about the sources of authority and power of 'social movements' and 'civil society' as a whole. 'Social movements' are generally conceived of as instantiations or elements of 'civil society'. ${ }^{17}$ Arguably, the idea of civil society has Western roots. The question of the origin, or provenance, of 'civil society' has been a subject of extensive debate, especially about the 
meaning, applicability and use of the idea of civil society in non-Western contexts like Africa (see, for example, Bratton 1989; Callaghy 1994; Comaroff and Comaroff 1999; Chandhoke 2001; Deakin 2001; Ferguson 1980; Gellner 1990; Howell and Pearce 2001; Hutchful 1998; Kavraji and Khilnani 2001). Not wishing to be drawn into the rather frustrating and sterile 'ancestry of civil society' debate, some African thinkers have even gone to the extent of proposing an 'alternative genealogy of civil society' for Africa (Obadare 2004).

\section{The idea of civil society in Africa}

Social movements, such as NGOs, are not a new phenomenon in Africa. Nyang'oro (cited in Bashaw, 2001) observes that NGOs 'have been actors on the development stage for several decades', prior to global financiers like the World Bank or global governmental organizations such the United Nations or any other official relief agency. Academic experts and higher education institutions 'discovered' NGOs and gave them international attention only in the mid-1980s (Nyang'oro, in Bashaw 2001: 251). For several years, NGOs have occupied a central place in people's economic and social life in Africa. NGOs' interventionist work in emergency food, refugee shelter and rehabilitation and in community development is acknowledged universally. Their intervention in Ethiopia's 1985/6 food crisis is inerasably memorable. Other than charity and relief, on the political plane, NGOs have successfully mobilized the people towards resistance against totalitarian rule, resulting in positive political change, for example, the United Democratic Front (UDF) in South Africa, Public Affairs Committee (PAC) in Malawi, and numerous others outside Africa such as in South America.

However, social movements in Africa are constrained and limited in important ways. The constraints are both structural/political (external to NGOs) and strategic (internal to NGOs). African states, argues Bashaw, 'are not much inclined to give enough room to enable NGOs to operate and function smoothly. This is certainly the case in Africa' (Bashaw 2001: 252). This is true for oppositional civic organizations. For most African states, NGOs are a thorn in the flesh. A case in point is Malawi where constitutional constraints are without doubt intended to contain and frustrate the political programmes and activities of NGOs. Malawi's NGO Act (2001) prevents NGOs from having, or appearing to have, 'objectives that are political in nature' or to indulge in 'partisan politics'. Khembo (2004) argues that this wording is vague, and it has led to arbitrariness in the interpretation of the act itself. Khembo feels pity for NGOs operating in Malawi because in practice, 'lack of clarity [in the NGO Act] has meant that ... the church, civil society organizations ... have invariably been accused of peddling "partisan politics"” 
(p 84), leaving NGOs in a very precarious position in which the NGO Board may at any moment cancel registration of a suspect NGO at will. For Khembo, it is accepted fact that 'civil society, especially the NGO community, is not entirely immune from calculated legal suffocation' (Khembo 2004: 86). The Malawian legislators seem to feel at ease with charitable NGOs - a purely economic civil society - but uneasy with NGOs that position themselves as oppositional civic organizations - a political civil society. No doubt, when Biowatch SA contested the South African state power by using the judicial machinery it positioned itself in an oppositional manner, and hence its selfevidential political nature.

Bashaw, however, cautions against our falling for a myth: the mere fact that NGOs do interventionist work does not imply that 'the people' can then trust them, 'simply because they are different from the state ... We cannot love NGOs just because they are nongovernmental' (Bashaw 2001: 253). Strategically, it is argued that most NGOs are ill-planned: their plans are short term and often geared to alleviating immediate consequences of poverty. NGOs do not plan in the long term, and so they 'give little attention to matters concerning development theory' (Cherret et al. in Bashaw 2001: 253). If they are assessed on the long-term basis, most NGOs do not seem to impact positively on poverty in Africa. Most people previously helped by NGOs remain trapped in the vicious cycle of abject poverty (UNDP 1993, in UNO 1995, in Bashaw 2001: 253). Yet, unlike states, NGOs are not directly accountable to 'the people' for issues of poverty, let alone development in any state. No citizenry or population group can blame an NGO for not delivering public utilities like water and electricity or for not providing in time basic property such as houses or land for houseless or landless majorities.

Thus, in spite of the efforts of Keane $(1998,2003)$ to revive our interest in 'the old idea', 'civil society' remains saddled with serious conceptual and empirical difficulties. As a subset of 'civil society', the idea of 'social movements' suffers from similar problems as 'civil society' does. Conceptual obscurantism, or definitional imprecision or fuzziness, leads to confusion as to what 'social movements' are - or ought be, as an ideal-type - and what their potency and agency could be in sociopolitical reality, for example, in Africa's postcolonial states.

\section{Political control of biotechnology in Africa: The people, civil society and the state}

The idea of 'social movements' raises an important question around the issue of the political control of biotechnology. The question is two-fold, involving both representation and accountability. Representation: because 
'social movements' claim to represent 'the people' - whether 'the people' are perceived as consumers, or as end-users of biotech products in their programmes and activities, while they simultaneously contest similar claims by the state and political party groupings to represent 'the people'. They claim to uphold 'public value' and to work to promote the 'public interest' or 'the general interest'. Accountability: because 'social movements' tend to position and express themselves as though sociopolitical accountability is categorical and not hypothetical - that is, an unconditional, and not a conditional (or prima facie) obligation. They believe that the state's accountability to 'the people' is categorical. Thus, the question is: from what source of authority (or mandate or legitimacy) can a 'social movement' claim to represent 'the people'?

The question is important because the issue of the political control of biotechnology does not directly suggest that social movements will get to decide whether or not we will control this new technology. Fukuyama, for example, is unequivocal about the collective identity of those who will get to decide about the political control of biotechnology, just as he is clear about the source of their authority (or mandate or legitimacy) in society. For him, decision- and policy-makers will be a

democratically constituted political community, acting chiefly through their elected representatives, that is sovereign in these matters and has the authority to control the pace and scope of technological development ... [i.e.] institutions that can capture the will of the people (Fukuyama 2002: 186).

Thus, when it comes to legislators - in parliamentary sovereignties - there is little or no doubt about the source of their political authority to represent 'the people' in decision- and policy-making on matters biotechnological. It is standard liberal democratic political thinking that legislators govern or lead by the general consent of 'the people' as voter-citizens. However, when it comes to 'social movements', as instantiations of 'civil society', it is not immediately clear what the source of their authority is.

Erstwhile theorization about the idea of 'civil society', from which the idea of 'social movements' is derived, is not helpful either. For example, theorists of 'civil society' here in the South are far from clear about the political potency and agency of the idea of civil society, thereby frustrating others to the extent of debunking the idea altogether. Mbembe (2001), for instance, thinks 'civil society' is yet to emerge in postcolonial Africa. For Mbembe, 'civil society' will emerge only when

places and spaces where ideas of autonomy, representation, and pluralism can publicly crystallize, and where juridical subjects enjoying rights and 
capable of freeing themselves from the arbitrariness of both state and primary group (kin, tribe, etc) can come into being (Mbembe 2001: 39).

Therefore, Mbembe envisions postcolonial 'civil society' in the form of autonomous - self-legislating and self-governing - associations and institutions of society that 'will articulate, autonomously and publicly, an idea of the general interest' (Mbembe 2001: 39). At present, all we seem to have on the ground is a multiplicity of disparate 'normative, economic, military and governmental spheres' that reflect a 'heteronomous and fragmented conception of the political community', instead of 'a consolidation of a constitutional state and right-bearing citizens in civil society' (Mbembe 2001: 39).

Other postcolonialist theorists, namely, Khilnani (2001) and Chatterjee (2001), cast more doubts over the political potency and agency of the idea of civil society. Khilnani thinks that in the South 'civil society is best thought of as a complicating term, one that embodies a range of historical idioms intended to establish a legitimate political order' (Khilnani 2001: 13). Contemporary scholarship is not in agreement about - and is yet to locate the proper location of the sources of 'civil society'. Is it in the economic, or the expressive, or the cultural? In other words, does 'civil society' reside in the economy, or 'in society independent of the economic domain' (i.e. interestbased associations 'where ideas are publicly exchanged'), or in 'a set of cultural acquisitions'? (Khilnani 2001: 13-14).

Hitherto, for Khilnani, the idea of civil society has not been deployed to ideal-typically refer to a substantive, determinate category in postcolonial states, whether it has been conceptualized as an idea distinct from, or opposed to, the state, or as a set of politicized, or depoliticized, or apolitical, associations that complement the state in governance functions, or normatively as 'moral and political' collective 'human capacities', or as an amalgam of 'commercial societies' (Khilnani 2001: 24-5). In spite of its 'promise' for sociopolitical change in the South, theorists of 'civil society' are conscious of the experimental if not elusive nature of the idea itself. Ultimately, Khilnani doubts the adequacy and even significance of the idea of civil society because 'in the task of developing viable and durable democratic politics in the South, the idea of civil society is hardly a self-sufficing one, let alone a fundamental "key" (Khilnani 2001: 32). Chatterjee debunks the idea of civil society altogether and opts for another idea which he christens as 'political society'. For Chatterjee, 'civil society', for example in postcolonial India, fails dismally to reach out to and represent wider society and the diversity of interests:

An important consideration in thinking about the relation between civil society and the state in the modern history of countries such as India is the fact 
that whereas the legal-bureaucratic apparatus of the state has been able ... to reach as the target of many of its activities virtually all of the population that inhabits its territory, the domain of civil social institutions ... is still restricted to a fairly small section of 'citizens'. The hiatus is extremely significant because it is the mark of non-western modernity as an always incomplete project of 'modernization' and of the role of enlightened elite engaged in a pedagogical mission in relation to the rest of society (Chatterjee 2001: 172).

Chatterjee seems to be relegating civil society organizations to elitist, Western-style special-interest associations that could hardly justify their claim to serving 'the general interest'. He claims that his idea of 'political society' will be more inclusive and more empowering in postcolonial states:

But then how are we to conceptualize the rest of society that lies outside the domain of modern society? The most common approach has been to use a traditional/modern dichotomy. One difficulty with this is the trap, not all easy to avoid, of de-historicizing and essentializing 'tradition'. I think a notion of political society lying between civil society and the state could help us see some of these historical possibilities. By political society, I mean a domain of institutions and activities where several mediations are carried out. (Chatterjee 2001: 172-3). ${ }^{18}$

Political societies may resort to strategic maneuvres, resistance and appropriation akin to those of political parties, but they are distinctively 'population groups' - and not bodies of citizens -whose demands on the state are based on 'the violation of the law'. They demand state welfare as a matter of right. The welfare functions, which political societies demand of the state, are seen as collective rights rather than as individual citizenship rights. The degree to which political societies are recognized by the state and NGOs depends on the pressure they are able to exert on state and non-state agencies (Chatterjee 2001: 177). In essence, political society stands for a community that comes into being spontaneously, for example, 'through the illegal occupation of a particular land or the collective illegal consumption of a public utility' such as 'associations of squatters, encroachers on public property, ticketless travelers on public transport, habitual defaulters of civic taxes, unauthorized users of electricity, water, or other public utility, and other such violators of civic regulations' (Chatterjee 2001: 177).

Chatterjee's substitute idea is forceful but not convincing. Chatterjee assumes there is a dichotomy between 'population' and 'citizenship'. Nevertheless, his assumption is questionable. His idea of 'political society' draws its conceptual force from the pragmatic idea of 'population', which is divested of its moral/legal demands, which are usually normatively imposed 
on political individuality - or 'citizenship' - in postcolonial states. The fact that violators of the law enjoy and benefit from collective rights does not necessarily imply that the state and non-state agencies will easily recognize their associations.

The pressure they are able exert on the state and non-state agencies is more about provision of property or access to public utilities than about the official recognition of their associations, which, in any case, violate or sidestep the law. Thus, although political societies often get what they demand as a collectivity, their 'illegal' deeds are bound to render them marginalized if not excluded from mainstream political programmes and activities. The possibility of marginalization or exclusion renders them weak and vulnerable 'subaltern publics'. Therefore, the notion of citizenship, which is infused with moral/ legal imperatives, is still crucial to our conception of individual or collective rights in a polity. On this, says Hawthorn (2001):

For states in the South ... whose capacities are now constrained ... associations concerned with civil rights can press issues of constitutional kind, those concerned with political rights for improvements in political procedures. And both are likely to be able more effectively to do so if there are opportunities for discussion and debate, opportunities that these associations, with others, might be able to do something to improve. But it is unrealistic to suppose that the associations can act greatly to extend the scope of powers of public policies to improve the well-being of the majority of the population. To be clear about the concept of 'civil society' is first to be clear about what citizenship can be, about what the state can do, about a point of politics itself (Hawthorn 2001: 286; my emphasis).

Hawthorn is hereby highlighting the interrelatedness of concepts of population, citizenship, politics and the state. Thus, even if the state deployed the concept of population for macro policy purposes or centralized planning - in the form of demographic statistics - it would not lose sight of the political nature - or citizenship status - of the population.

\section{Conclusion}

The problematic idea of the democratization of science is multi-issue in scope and is a multi-stakeholder effort. The idea is important because it provides the basis for thinking more deeply about biotechnological development in South and southern Africa. Science communication and public understanding of biotechnology do not make sense outside the framework of the democratization of science. Hitherto, scholarly attention has focused only on the role of scientists and news media in making science more and more accessible to wider society, especially to non-expert publics. Scientists are 
accused generally of being poor communicators of their own trade, preferring to work in isolation behind closed doors, in laboratories. News media practitioners are accused generally of misrepresenting science in public domains. Social movements, as elements of civil society, raise a hope of filling the gap left by both scientists and news media practitioners. Looking at Biowatch SA's intervention in GM regulation in South Africa some years ago, one could see that there is room for such hope. At least to start with, one could see that the processes of the democratization of science are not the prerogative of one group of stakeholders such as the state, scientists or news media practitioners. Yet the idea of civil society is swamped in confusion at present. Thus, there are reasonable doubts about its political potency and agency to help democratize the new science and technology (biotechnology) - that is to bring biotechnology to 'the people'. Moreover, the idea's pretensions to introducing and sustaining any desired sociopolitical change in southern Africa need to be interrogated further.

There is little or no doubt though that social movements have, at least at the empirical level, made their presence felt in South and southern Africa, in Africa at large, as well as at the global level. A social movement such as Biowatch SA would definitely be one to reckon with in South Africa. Once more, Biowatch SA managed to draw the attention of the high court, sued the state and the biotech corporate industry, and eventually won its 'public interest' case. However, in spite of such anecdotal evidence of their integration into wider society, social movements still occupy a theoretically obscure and politically contested space in Africa. The meaning of the idea of civil society, together with its attendant ideas such as social movements and NGOs, is not only conceptually fuzzy but also relentlessly contested by traditional sources of power and authority such as state agencies, political parties and trade unions, which have enjoyed and still enjoy moderately tidy and neat conceptualizations. Since the meaning of the idea of civil society is unclear, rendering theorization obscure, clear and tidy conclusions about the democratization -that is, the sociopolitical control - of science and technology in the region, or the continent at large, are not easy to reach.

In spite of the fuzziness of the idea of civil society, some would be hesitant to leave all policy, regulation and control on biotechnology in the hands of 'parliamentary sovereignties' (Fukuyama 2002) or 'strong publics' (Fraser 1993). These traditional sources of power and authority can help democratize science and technology. African states might be resource-poor, inefficient in terms of service delivery, generally corrupt and the least accountable to 'the people', but they are largely strong states. ${ }^{19}$ South Africa's big drive towards the democratization of science is testimonial to, or at least indicative of, a 
strong state. Although the emergence of 'strong' ${ }^{20}$ states does not preclude the growth of a strong civil society, oppositional civil organizations in Africa are politically constrained and limited in important ways. Biowatch's legal victory against the state and the biotech corporate industry raises Mbembeian and Keanian quasi-utopian visions of a future African deliberative democratic public sphere, an abstract 'becoming', with a bit of luck to be realized when 'the people' are mobilized by civil society organizations - rather than solely by political parties and trade union - to participate in societal deliberations on matters biotechnological, in particular, and, scientific and technological, in general.

Finally, the paper recommends more issue-specific and multi-stakeholder studies in things biotechnological at both country and regional level. Regardless of whether the idea of civil society is original or derivative, in-depth research on the idea is required in order to further clarify its conceptual-epistemological status or meaning and its conditions of applicability and use in South and southern Africa. Generally, future research in science communication and public understanding of biotechnology in South and southern Africa might further illumine the complexities of 'the democratization of science' in South and southern Africa and Africa as a whole.

\section{Notes}

1. Moreover, although it is the least significant concern for this paper, civil society organizations are uncoordinated in their goals and interventions in Africa, leading to duplication and wastage of their otherwise worthwhile interventionist efforts.

2. The background idea to deliberative democracy is that of the public sphere for deliberations as envisioned by Habermas (1962, translated into English in 1989).

3. See, for example, HSRC Review 2005: 2, July, for South Africa's low level and poor quality of 'public understanding' of biotechnology.

4. See, for example, Mwale (2005a, 2006) for Zambia's near-zero level and very poor quality of public understanding of biotechnology. See also Chinsembu and Kambikambi (2001).

5. Genomics and Society, 2004.

6. The South African parliament amended the GMO Act (1999) in January 2006. See SA GMO Amendment Bill (2006).

7. Poster on Public Understanding of Biotechnology, 2005, South African Agency for Science and Technology Advancement (SAASTA).

8. Genomics and Society, 2004.

9. See http://www.saasta.ac.za/scicom/index.shtml (retrieved in June 2007).

10. See http://www.pub.ac.za/about/index.html (retrieved in June 2007).

11. See http://www.saasta.ac.za/sascon/index.shtml (retrieved in June 2007). 
12. A number of factors, three of which are the most worrisome, beset non-experts' participation in science communication: ignorance, the language barrier and resource-poverty. On non-experts' ignorant of science, in 2004, an HSRC client survey of a representative sample of 7000 adults showed that about $80 \%$ of South African non-experts did not know, or had no knowledge of, biotechnology. An average of $73 \%$ did not know if genetic modifications were either positive or negative (HSRC Review, 2005: 2). In South Africa, the abovecited 2004 HSRC client survey showed that the media comes second to the university as 'the most trusted institution to provide reliable information on biotechnology' (HSRC Review 2005: 2).

13. The Mercury, 5 May 2004.

14. The Mail\&Guardian, 9 March 2005.

15. Cape Argus, 5 March 2005.

16. The City Press, 28 October 2005.

17. The view that 'social movements' are a subset of 'civil society' commands wide consensus in contemporary social critical theory. For example, Greenstein (2005) perceives post-Apartheid South Africa's 'new social movements' as 'elements of civil society'. He likens them to Fraser's 'subaltern publics', i.e. 'arenas for debate and contestation'. He is interested in how 'the new social movements ... create in the discussion of alternative policies, modes of organization, and social and political visions' (Greenstein 2005: 5). Hawthorn (2001) describes 'civil society as the great variety of social movements ... whose purposes and direction are not controlled by the institutions of the state' (Hawthorn 2001: 276). Khilnani (2001) is worried that an exclusive focus on 'social movements' that exist outside 'high politics' and the party system, as the crucial agent for the creation of a civil society and 'democratization', yields an overly partial perspective. Khilnani complains that the exclusive focus on 'social movements ... avoids questions about the abilities of social movements to secure both stable and durable institutional form and to embody self-limiting properties: if they are to govern, what governs?' But he does not commit himself to proposing an alternative to 'social movements', i.e. as the crucial agents in the emergence of civil society in the South (Khilnani 2001: 31). Tester (1992) looks at 'civil society as a label applicable to all those social relationships which involve the voluntary association and participation of individuals acting in their private capacities'(Tester 1992: 8).

18. Political society is only feasible where the definitive concept is that of population, because though 'differentiated', it is 'classifiable, describable, and enumerable' - unlike citizenship. Chatterjee says he is indebted to Michel Foucault (History of Sexuality. Harmondsworth: Viking, 1985) for rudiments of the idea of 'political society'. For Chatterjee, Foucault 'has been more perceptive than other social philosophers of recent times in noticing the crucial importance of the new concept of population for the emergence of modern governmental technologies... Perhaps we should also note the contribution 
here of colonial anthropology and colonial administrative theories' (Chatterjee 2001: 173).

19. For Migdal (1988), apart from having ‘strongmen’ [powerful leaders], strong states are also characterized by 'strong state agencies', which exercise 'social control' on the population because they have 'channels to the population to induce mobilization through a viable mix of rewards, sanctions and symbols' (Migdal 1988: 210). In an ANC-majority-led government, it would be unusual for the South African state not to be considered 'strong'.

20. The binary 'strong/weak' in the categorization of states is without doubt only a speculative - and not a practical - idea. In practical reality, most states would lie somewhere midway along the continuum strong-to-weak. Recently, an empirical study used what was called the Minorities at Risk Database to impose this characterization on sub-Saharan African states. This study gives us one of the latest attempts at empirical definitions of a 'strong' or 'weak' state. Analysts Atiku-Abubakar and Shaw-Taylor used 'inter-communal conflict' to measure and describe the attributes of a sub-Saharan African 'weak state' as one 'having a prevalence of structural inequality, the components of which are economic differentiation, cultural (or social) inequality and political inequality' (Atiku-Abubakar and Shaw-Taylor 2003: 168). This empirical definition is far from clear, let alone precise as to what constitutes 'weaknesses' in a state.

\section{References}

Atiku-Abubakar, J.J. and Shaw-Taylor, Y., 2003, 'An empirical profile of weak states in sub-Saharan Africa', Africa Development XXVIII (3\&4): 168-185.

Ballard, R., Habib, A. and Valodia, I. (eds), 2006, Voices of Protest: Social movements in post-apartheid South Africa, Scottsville: University of KwaZulu-Natal Press.

Bashaw, Z.N., 2001, 'NGO-government relations: Conflict and co-operation in development management for rehabilitation of demobilized soldiers: The case of Eastern Tigray, Ethiopia', Africa Development XXVI (1\&2): 251-294.

Bratton, M., 1989, 'Civil society and associational life in Africa', World Politics 41(3): 407-430.

Buck, J.A., Dent, E.B. and Umpleby, S.A., 2000, Commentary: Communicating science, Science Communication 22(1): 73-87.

Callaghy, T.M., 1994, 'Civil society, democracy, and the state in Africa: A dissenting opinion about resurgent societies', in Haberson, J., Rothchild, D. and N. Chazan, N. (eds), Civil Society and the State in Africa, London: Lynne Rienner, pp. 231-254.

Comaroff, J.L. and Comaroff, J. (eds), Civil Society and the Political Imagination in Africa: Critical perspectives, Chicago: University of Chicago Press.

Chandhoke, N., 2001, “The 'civil' and the 'political' in civil society", Democratization 8(2) (Summer): 1-24. 
Chatterjee, P., 2001, 'On civil and political society in postcolonial states, in Kaviraj, S. and Khilnani', S. (eds), Civil Society: History and possibilities, Cambridge: Cambridge University Press, pp. 165-178.

Chinsembu, T. and Kambikambi, T., 2001, 'Farmers' perceptions and expectations of genetic engineering in Zambia', Biotechnology and Development Monitor $47 ; 13-15$.

Cook, G., Robbins, P.T. and Pieri, E., 2006, 'Words of mass destruction': British newspaper coverage of the genetically modified debate, expert and non-expert reactions, Public Understanding of Science 15(1): 5-29.

Corbett, J.B. and Durfee, J.L., 2004, 'Testing public (un)certainty of science: Media representations of global warming', Science Communication 26(2): 129-151.

Deakin, N., 2001, In Search of Civil Society, Basingstoke: Palgrave.

Ferguson, A., 1980, An Essay on the History of Civil Society, with a new introduction by L. Schneider, New Brunswick, NJ: Transaction Books.

Fraser, N., 1993, 'Rethinking the public sphere: A contribution to the critique of actually existing democracy, in Calhoun', C. (ed.), Habermas and the Public Sphere, Cambridge, MA: Polity Press, pp. 109-142.

Fukuyama, F., 2003, Our Posthuman Future: Consequences of the biotechnology revolution, London: Profile Books.

Gellner, E., 1995, 'Civil society and its future, in Hall', J.A. (ed.), Civil Society: Theory, History, Comparison, Cambridge, MA; MIT/Polity Press.

Greenstein, R., 2005, 'Social movements and public intellectual life, Johannesburg: University of the Witwatersrand' (unpublished).

Gutteling, J., Hanssen, L, van der Veer, N. and Seydel, E., 2006, 'Trust in governance and the acceptance of genetically modified in the Netherlands', Public Understanding of Science 15(1): 103-112.

Habermas, J., 1989, The Structural Transformation of the Public Sphere: An inquiry into a category of bourgeois society. Cambridge, MA: MIT Press.

Hawthorn, G., 2001, 'The promise of 'civil society' in the South, in Kaviraj, S. and Khilnani', S. (eds), Civil Society: History and possibilities, Cambridge: Cambridge University Press, pp. 269-286.

Hijmans, E., Pleitjter, A. and Wester, F., 2003, 'Covering scientific research in Dutch newspapers', Science Communication 25(2): 153-176.

Horst, M., 2005, 'Cloning sensations: Mass mediated articulation of social responses to controversial biotechnology', Public Understanding of Science 14(2): 185-200.

Howell, J. and Pearce, J., 2001, Civil Society and Development: A critical exploration, London: Lynne Rienner.

HSRC Review, 2005, 'Bio what? Public has scant knowledge of biotechnology', HSRC Review,3(2) (July): 2.

Huijer, M., 2003, 'Reconsidering democracy: History of the Human Genome Project', Science Communication 24(4): 479-502.

Hutchful, E., 1998, 'The civil society debate in Africa', International Journal 51(1): 54-77. 
Joubert, M., 2001, 'Report: Priorities and challenges for science communication in South Africa', Science Communication 22(3): 316-333.

Keane, J., 1998, Civil Society: Old images, new visions, Cambridge, MA: MIT/ Polity Press.

Keane, J., 2003, Global Civil Society?, Cambridge: Cambridge University Press.

Khanna, J., 2001, 'Science communication in developing countries: Experience from WHO workshops', Science Communication 23(1): 50-56.

Khembo, N.S., 2004, 'The multiparty promise betrayed: The failure of neo-liberalism in Malawi', Africa Development XXIX (2): 80-105.

Khilnani, S., 2001, 'The development of civil society, in Kaviraj', S. and Khilnani, S. (eds), Civil Society: History and possibilities, Cambridge: Cambridge University Press, pp 11-32.

Larson, B.M.H., Nerlich, B. and Wallis, P., 2005, 'Metaphors and biorisks: The war on infectious diseases and invasive species', Science Communication 26(3): 243-268.

Latour, B., 1987, Science in Action: How to follow scientists and engineers through society, Cambridge, MA: Harvard University Press.

Logan, R.A., Park, J. and Shin, J., 2004, 'Elite sources, context, and news topics: How two Korean newspapers covered a public health crisis', Science Communication 25(4): 364-398.

Mandela, N.R., 1994, cited in Preface to White Paper on Science and Technology, 4 September 1996, Department of Arts, Culture, Science and Technology, Republic of South Africa. Pretoria.

Manzini, S., 2003, 'Effective communication of science in a culturally diverse society', Science Communication 25(2): 191-197.

Mbembe, A., 2001, On the Postcolony, Berkeley: University of California Press.

McInerney, C., Bird, N. and Nucci, M., 2004, 'The flow of scientific knowledge from lab to the lay public: The case of genetically modified food', Science Communication 26(1): 44-74.

Migdal, J.S., 1988, Strong Societies and Weak States, Princeton: Princeton University Press.

Migdal, J.S., 2001, State in Society, Cambridge: Cambridge University Press.

Mountcastle-Shah, E., Tambor, E, Bernhardt, B.A. et al., 2003, 'Assessing mass media reporting of disease-related genetic discoveries', Science Communication 24(2): 458-478.

Mwale, P.N., 2005a, 'Public debates and societal deliberations: The case of the Zambian National Consultation on GM Maize Food Aid in 2002', Paper presented at the Science and Democracy Conference 3, Institute of Philosophy, Naples, Italy, 20-22 October. See http://www.dipmat.unipg.it/ mamone/scidem/introduction.htm

Mwale, P.N., 2005b, 'GM Maize Food Aid in Zimbabwe (2001-2004)', Johannesburg: University of the Witwatersrand (unpublished).

Mwale, P.N., 2006, 'Societal deliberation on genetically modified maize in southern Africa: The debateness and publicness of the Zambian national consultation 
on genetically modified maize food in 2002', Public Understanding of Science 15(2): 89-102.

Obadare, E., 2004, 'The alternative genealogy of civil society and its implications for Africa: Notes for further research', Africa Development XXIX (4): 1-18.

Pelletier, D., 2005, 'Food safety and consumer choice policy, in Owamo', S.W. and von Grebmer, K. (eds), Biotechnology, Agriculture, and Food Security in Southern Africa, Washington, DC and Harare: IFPRI and FANRPAN, pp. 113156.

Roche, J.P. and Muskavitch, M.A.T., 2003, 'Limited precision in print and media communication of West Nile Virus risks', Science Communication 24(3): 353365.

Shoemaker, P.J. and Reese S.D., 1996, Mediating the Message: Theories of influences on mass media content, London: Longman.

Smith, J., 2004, Seeds of Deception, London: Green Books.

Tanner, A.H., 2004, 'Agenda building, source selection, and health news at local television stations: A nationwide survey of local television health reporters', Science Communication 25(4): 350-363.

Tester, K., 1992, Civil Society, London and New York: Routledge.

Trumbo, C.W., Dunwoody, S. and Griffin, R.J., 1998, 'Journalists, cognition and the presentation of an epidemiological study', Science Communication 19(3): 238-265.

Van der Walt, W.J., 2000, 'South Africa and the global biotechnology battle', BIOY2K Combined Millennium Meeting: Programme and Abstracts, Grahamstown: Rhodes University, 23-28 January, pp. 34-35.

Walters, L.M. and Walters, T.N., 2006, 'It loses something in the translation: Syntax and survival of key words in science and nonscience press releases', Science Communication 18(2): 165-180.

Weigold, M.F., 2001, 'Communicating science: A review of the literature', Science Communication 23(2): 164-193.

Weingart, P., Engels, A. and Pansegrau, P., 2000, 'Risks of communication: Discourses on climate change in science, politics, and the media', Public Understanding of Science 9: 263-283. 